(ICSSE 2020)

\title{
Peatland Economic Revitalization Program Based on Community Participation in Jarenang Village, Kuripan District, Barito Kuala Regency, South Kalimantan
}

\author{
Sri Wahyuni Pratiwi ${ }^{1}$ Karunia Puji Hastuti ${ }^{1 *}$ Eva Alviawasti ${ }^{1}$ \\ Akhmad Munaya Rahman ${ }^{1}$ \\ ${ }^{1}$ Department of Geography Education, Faculty of Teacher Training and Education, Lambung Mangkurat University, \\ Banjarmasin, Indonesia \\ ${ }^{*}$ Corresponding author. Email: karuniapuji@ulm.ac.id
}

\begin{abstract}
This study aims to analyze community participation in the peatland economic revitalization program in Jarenang Village, Kuripan District, Barito Kuala Regency. This type of research is descriptive qualitative. The data analysis techniques used were data collection, data reduction, data presentation, and data conclusion or verification. The results showed that the stages of community participation consist of the planning stage of community programs, always being involved in every program through conveying ideas/suggestions/opinions because of ideas and suggestions from the community. The implementation stage of community activities is always involved, community participation by working together, providing facilities and maintaining facilities and infrastructure for the success of a program both in terms of energy and thoughts. The evaluation phase of community programs is always involved in evaluation meeting activities. The yield utilization stage for purun plant cultivation in utilizing the yield cannot be carried out because the purun plants have not been harvested, while for tilapia cultivation in floating nets the community is involved in utilizing the results and maintaining the results.
\end{abstract}

Keywords: Community Participation, Economic Revitalization, Peatlands

\section{INTRODUCTION}

Geography is the study of the similarities and differences of geosphere phenomena from the perspective of their environment or territory in a spatial context. The concept of geography presented above clearly emphasizes that the object of geographic study is none other than the geosphere, namely the earth's surface which is essentially part of the earth which consists of the atmosphere (air layer), lithosphere (rock layer, earth crust), hydrosphere (layer). water, waters), and the biosphere (layer of life). Presidential Regulation Number 1 of 2016 concerning the Peat Restoration Agency is contained in article 2 of the Peat Restoration Agency has the task of coordinating in 7 provinces which are prioritized by the Peat Restoration Agency, namely, South Kalimantan Province [1].

The Peatland Restoration Agency has implemented the 3R program (Revitalization, Revegetation and Rewetting). The revitalization program is one of the programs carried out by the Peat Restoration Agency and real government action. A community-based economic revitalization program through the involvement of all communities and an approach that is responsive to community needs $[1,2]$. The first revitalization program package carried out by the Peat Restoration Agency (BRG) in Jarenang Village, Kuripan District, Barito Kuala Regency, namely cultivating tilapia in floating nets as business development and increasing community income, which currently depend on river and swamp waters as a place to find. living.

Revitalization, particularly in the fisheries sector, aims to increase the added value of fishery products, as well as the income of fishermen, fish cultivators and other coastal communities (Ministry of Marine Affairs and Fisheries, 2005). This can be seen in reality, where one side of fishery products is a source of animal protein which has become one of the non-oil and gas export commodities and a source of foreign exchange. On the other hand, farmers / fishermen as the main actors of the agribusiness subsystem of farming / cultivation only get the smallest part of all agribusiness actors, even some are still shackled by poverty.

The revitalization program package carried out by the Peat Restoration Agency (BRG) in Jarenang Village, Kuripan District, Barito Kuala Regency in addition to cultivating tilapia, namely the lake purun plant. Lake purun plants, if managed properly, can be used as a booster for regional economic development [3]. The reason for choosing Jarenang Village as the research site was because the village was included in the four villages which were the priority areas of the Peat Restoration Agency. The community can optimize the utilization of the area through 
an economic revitalization program to support economic needs with a small population of Jarenang Village [4].

Community participation is very important for the realization of the results of the implementation of the economic revitalization program, so it is necessary to know the participation of the community in the economic revitalization program. The role of the community helps in understanding and strengthening local communities in increasing the peatland area.

\section{RESEARCH METHOD}

Jarenang Village is located in Kuripan District, Barito Regency, Kuala Kalimantan, South Kalimantan. Jarenang village is astronomically located between latitude $2^{\circ} 39^{\prime} 50,532$ "latitude-114 $47^{\prime} 45,228^{\prime \prime}$ east longitude [4]. This research is qualitative. Respondents in this study were 30 people who participated in the revitalization program for tilapia aquaculture in floating nets and purun lakes in Jarenang Village, Kuripan District, Barito Kuala Regency. The data analysis technique used was data collection, data reduction, data presentation and data conclusion [5].

\section{RESULTS AND DISCUSSION 3.1 Stages of Public Participation \\ 3.1.1 Planning \\ 3.1.1.1 Economic Revitalization Program through Purun Danau Cultivation}

Communities who take part in the purun Danau cultivation economic revitalization program participate in the program planning stages such as socialization, deliberation and counseling. The community who participated in the purun plant cultivation economic revitalization program when the socialization activities were held were involved, such as group leaders, group deputy heads, secretaries, treasurers, group members, village officials and the Peat Restoration Agency (BRG). The determination of the program package was chosen based on the mutual agreement of members of the purun Danau plant cultivation group and the Peat Restoration Agency agreed that with the selection of an economic revitalization program for purun Danau plants to be cultivated, a program was chosen to be carried out, namely the economic revitalization program for purun Danau plant cultivation. The location of the program was chosen based on the agreement of the deliberations with members of the purun plant cultivation group and the Peat Restoration Agency. Community activity in participating in extension activities can be seen that not all group members participate in extension activities held by the Peatland Restoration Agency.

\subsubsection{Economic Revitalization Program through Tilapia Cultivation in Floating Nets}

Communities who participate in the economic revitalization program for tilapia aquaculture in floating nets participate in the program planning stages such as socialization, deliberations and counseling. Communities who take part in the economic revitalization program for tilapia aquaculture in floating nets during socialization activities are involved, such as group leaders, group deputy heads, secretaries, treasurers, group members, village officials and the Peat Restoration Agency (BRG). When this activity is held, the person chosen to be the management structure based on the results of the deliberations and the people who participate in the economic revitalization program for tilapia aquaculture in floating nets are always present and play an active role in conveying ideas / suggestions / opinions on program and location determination.

The determination of the program package was chosen based on the mutual agreement of members of the tilapia aquaculture group in floating nets and the Peat Restoration Agency agreed with the selection of an economic revitalization program for tilapia aquaculture in floating nets to be cultivated, so a program was chosen, namely the economic revitalization program for tilapia aquaculture in floating nets $[6,7]$. The location of the program was chosen based on the agreement of deliberations with members of the tilapia fish group in floating nets and the Peat Restoration Agency. Community activity in participating in extension activities can be seen that not all group members participate in extension activities held by the Peatland Restoration Agency.

The results of the research are in accordance with the theory stated by Adisasmita, 2006 in Andreeyan [8], that community participation in programs is the involvement of community members in the planning and implementation stages of development programs. Community involvement in supporting the economic revitalization program for purun Danau plant cultivation and tilapia cultivation in floating nets is important for the realization of an advanced program because of the cooperation between communities participating in the economic revitalization program for purun Danau cultivation and tilapia aquaculture in floating nets.

\subsubsection{Implementation}

\subsubsection{Economic Revitalization Program through Purun Danau Cultivation}

All people who take part in the purun Danau cultivation economic revitalization program participate in the implementation phase of the program. Members of the purun Danau cultivation group are involved in providing experiences and knowledge to develop the purun Danau cultivation economic revitalization program. The members of the purun Danau cultivation group are involved in planting purun. Provision of facilities provided by one of the members of the purun Danau cultivation group. The program maintenance process is carried out by all group members. Members of the purun Danau cultivation group are not involved in providing money or assets during the program implementation stage. 


\subsubsection{Economic Revitalization Program through Tilapia Cultivation in Floating $\underline{\text { Nets }}$}

All people who take part in the economic revitalization program for tilapia aquaculture in floating nets participate in the program implementation stage. Members of floating net tilapia aquaculture groups are not involved in providing experience and knowledge to develop an economic revitalization program for tilapia aquaculture in floating nets because the group members have no experience. Members of the tilapia farming group in floating nets are involved in building the site. Provision of facilities provided by one of the members of the tilapia farming group in floating nets. The program maintenance process is carried out by all group members. Members of the tilapia farming group in floating nets are not involved in giving money or assets during the program implementation stage.

The research results are supported by Cohen and Uphoff's theory in Isaac [9] participation in the implementation with a tangible form of participation of manpower, money and assets.

\subsubsection{Evaluation}

\subsubsection{Economic Revitalization Program through Purun Danau Cultivation}

All people who participate in the purun Danau cultivation economic revitalization program are not all group members involved in the stage of enjoying the benefits of the program. Members of the purun Danau cultivation group have not enjoyed the benefits of increasing income to support community welfare. This program is of important value, especially for people who participate in the economic revitalization program through the cultivation of purun Danau plants, because this program can be used to increase the income of group members from the harvest. The members of the purun Danau cultivation group are not involved in maintaining the program results.

\subsubsection{Economic Revitalization Program through Tilapia Cultivation in Floating Nets}

All people who participate in the economic revitalization program for tilapia aquaculture in floating nets are not all group members involved in the stage of enjoying the benefits of the program. Members of the tilapia aquaculture group in floating nets have not enjoyed the benefits of increased income to support community welfare. This program is of important value, especially for people who take part in the economic revitalization program through tilapia aquaculture in floating nets, because this program can be used to increase the income of group members from the harvested fish. Members of the tilapia farming group in floating nets are involved in maintaining the program results.

The results of this study are in accordance with the opinion of Cohen and Uphoff in Kalesar et al [10], stated that participation is divided into 4 stages, namely participation in program planning decisions, participation in program implementation, participation in benefiting and participation in program evaluation. Participation in program evaluation aims to determine the achievement of previously planned programs. Community participation in program evaluation is related to providing input for improvement of program implementation, community involvement in participating in evaluation meeting activities, evaluating the appropriateness of planning and implementation, and monitoring if there are problems in the economic revitalization program for purun Danau cultivation and tilapia aquaculture in floating nets.

\subsubsection{Utilization of Results \\ 3.4.1.1 Economic Revitalization Program through Purun Danau Cultivation}

All people who take part in the purun Danau cultivation economic revitalization program are not involved in the evaluation meeting stage. Members of the purun Danau cultivation economic revitalization program group evaluated that the suitability of the planning and implementation of the program was appropriate but the results were not appropriate, because the seeds of the purun plants that had just been planted died. In the supervision phase, the implementation of the economic revitalization program through purun Danau cultivation, not all members of the purun plant cultivation group are involved. Members of the purun Danau cultivation group are not involved in providing criticism, suggestions and assessments, because the results of the economic revitalization program through purun Danau cultivation cannot be assessed and the results of the purun plants are not yet known whether this program is successful or not $[11,12,13]$.

\subsubsection{Economic Revitalization Program through Tilapia Cultivation in Floating $\underline{\text { Nets }}$}

All people who participate in the economic revitalization program for tilapia aquaculture in floating nets are not involved in the evaluation meeting stage [14]. Members of the economic revitalization program for tilapia aquaculture in floating nets evaluate that the appropriateness of the planning and implementation of the program is appropriate but the results are not suitable, because many tilapia fish seedlings die from water[15,16]. Not all members are involved in the implementation of the economic revitalization program through tilapia in floating nets. Communities who take part in the economic revitalization program through tilapia cultivation in floating nets are involved in providing criticism, suggestions and assessments of programs where the program has obstacles, so the advice to cultivate tilapia depends on the season and if you can add more seeds because there are already a lot of fish. who died from palm oil waste water.

The results of this study are in accordance with the opinion of Cohen and Uphoff in Kalesar et al[10], stated that 
participation is divided into 4 stages, namely participation in program planning decisions, participation in program implementation, participation in benefiting and participation in program evaluation. Participation in taking benefits cannot be separated from the results of program implementation related to quality and quantity. Community participation in the utilization of the results in the form of enjoying the benefits of the results, the benefits of program activities and assessing the importance of the existence of program results.

\section{CONCLUSION}

The stages of community participation consist of four stages, namely: First, in the planning stage of the community program, they are always involved in every program by conveying ideas / suggestions / opinions because ideas and suggestions from the community are used as consideration to determine what is needed in the program planning process. Second, the implementation of community activities is always involved, community participation by working together, providing facilities and maintaining facilities and infrastructure for the success of a program both in terms of energy and thoughts. Third, in program evaluation, the community is always involved in evaluation meeting activities and the community is always involved in providing criticism, suggestions and assessments of the program. The community evaluates the appropriateness of planning and implementation of programs for purun lake cultivation and tilapia cultivation in floating nets, such as purun plant cultivation the appropriateness of planning and program implementation is appropriate, but the results cannot be said to be appropriate or not, while tilapia cultivation in floating nets is according to planning and the implementation of the program is appropriate, but the results are not suitable because many fish die from palm oil waste water. Fourth, it is not possible to utilize the produce for purun plant cultivation because the purun plant has not been harvested, while for tilapia cultivation in floating nets the community is involved in utilizing the produce and maintaining the produce. In this study, only 2 packages of economic revitalization programs were used, namely the purun Danau cultivation program and the Tilapia cultivation program in floating nets. It would be better if the revitalization program was added like galam plant.

\section{REFERENCES}

[1] Badan Restorasi Gambut, Laporan Kemajuan Tahap I Pengembangan Ekonomi Masyarakat Melalui Budidaya Perikanan Rawa. Banjarmasin: Badan Restorasi Gambut, 2017.

[2] and D. A. Bunga Karnisa Goib, Nadia Fitriani, Satrio Adi Wicaksono, Muhammad Yazid, "KERAJINAN ANYAMAN DARI PURUN SEBAGAI SALAH SATU BENTUK USAHA BERKELANJUTAN DI KABUPATEN OGAN KOMERING ILIR (OKI), SUMATERA SELATAN," J. Anal. Kebijak. Kehutan., vol. 16, no. 1, pp. 67-87, 2019.

[3] D. Harsono, "Sifat Fisis Dan Mekanis Purun Bajang Sebagai Substitusi Purun Danau Dan Purun Tikus," J. Ris. Ind. Has. Hutan, vol. 5, no. 2, p. 45, 2013, doi: 10.24111/jrihh.v5i2.1218.

[4] BPS Kecamatan Kuripan, "Kecamatan Kuripan dalam Angka 2017," Barito Kuala, 2017.

[5] A. F. Damanik, "Tingkat Pemanfaatan E-Journal Clinicalkey Oleh Mahasiswa Kedokteran Di Perpustakaan Fakultas Kedokteran Universitas Islam Sultan Agung Semarang," J. Ilmu Perpust., vol. 4, no. 3, pp. 1-10, 2015, [Online]. Available:

https://ejournal3.undip.ac.id/index.php/jip/article /view/9718/9441.

[6] W. Alawiyah and R. Yuliasari, "PENDAPATAN USAHA BUDIDAYA IKAN NILA (Oreochromis sp) DALAM KERAMBA JARING APUNG DI DESA PEMATANG JERING KECAMATAN JAMBI LUAR KOTA KABUPATEN MUARO JAMBI," J. MeA (Media Agribisnis), vol. 4, no. 2, p. 84, 2019, doi: $10.33087 /$ mea.v4i2.52.

[7] Y. Hasiani, "EFISIENSI FAKTOR-FAKTOR PRODUKSI USAHA PEMBESARAN IKAN NILA DALAM KARAMBA JARING APUNG DI KABUPATEN BANJAR," Yarna Hasiani/Enviroscienteae, vol. 11, pp. 187-192, 2015.

[8] R. Andreeyan, "Studi Tentang Partisipasi Masyarakat dalam Pembangunan Di Kelurahan Sambutan Kecamatan Sambutan Kota Samarinda," eJournal Administrasi Negara, vol. 2, no. 4. p. 1940, 2014.

[9] Fistarisma Ishak, Rostin dan Ambo Wonua Nusantara, "Analisis partisipasi masyarakat dalam menunjang pembangunan desa di kecamatan tongauna kabupaten konawe," $J$. Ekon., vol. 1, no. 1, pp. 67-79, 2016.

[10] N. P. Ferdinand Kalesaran, Ventje Rantung, "PARTISIPASI DALAM PROGRAM NASIONAL KELURAHAN TAAS KOTA MANADO Oleh: Ferdinand Kalesaran PENDAHULUAN Model pembangunan partisipatif dapat dikatakan sebagai suatu bentuk reaksi atas manajemen pembangunan yang berparadigma atau bermodelkan neo-liberalisme y," e-journal Acta Diurna, vol. IV, no. 5, 2015.

[11] S. A. Sari, "Respon Pertumbuhan Purun Danau (Lepironia Articulata Retz. Domin) Terhadap Komposisi Media Tanam," Universitas Sriwijaya, 2020.

[12] H. Widhoyo, K. Kurdiansyah, and Y. Yuniarti, "UJI FITOKIMIA PADA TUMBUHAN PURUN DANAU (Lepironia articulata)," $J$. Sylva Sci., vol. 02, no. 3, pp. 484-492, 2020, [Online].
Available: 
http://ppjp.ulm.ac.id/journals/index.php/jss/articl e/view/1828.

[13] dan H. I. Rahmalia, H.E. Handayani, "Penetralan Air Asam Tambang Menggunakan Tumbuhan Purun Tikus (Elocharis Dulcis)," J. Pertamb., vol. 4, no. 2, pp. 67-73, 2020.

[14] R. F. Pangestu, "KAJIAN ASPEK EKONOMI MASYARAKAT DALAM PENGEMBANGAN BUDIDAYA IKAN DI KECAMATAN WASILE KABUPATEN HALMAHERA TIMUR PROVINSI MALUKU UTARA," Universitas Pancasakti Tegal, 2020.
[15] M. B. Syamsunarno and M. T. Sunarno, "Budidaya ikan air tawar ramah lingkungan untuk mendukung keberlanjutan penyediaan ikan bagi masyarakat," Semin. Nas. Perikan. dan Kelaut. 2016. Pembang. Perikan. dan Kelaut. dalam Mendukung Kedaulatan Pangan Nas., no. January 2016, pp. 1-16, 2016.

[16] M. Panjaitan, "Kajian Potensi Indeks Pertanaman 200 Pada Lahan Rawa Lebak di Desa Pelabuhan dalam Kecamatan Pemulutan Kabupaten Ogan Ilir," Universitas Sriwijaya. 